\title{
ZMIENIAJĄCA SIĘ SZKOŁA WOBEC WYMAGAŃ RYNKU PRACY, I NIE TYLKO
}

Streszczenie: Celem artykułu jest ukazanie sytuacji szkoły w kontekście zmieniającej się rzeczywistości i wymagań rynku pracy. Zaprezentowano nowoczesne wymiary szkoły oraz przykłady projektów Modelu Szkoły Ćwiczeń. Podjęto kwestie rozwoju gospodarki cyfrowej oraz związanych z nią kompetencji przyszłości, a także roli nauczyciela w zmieniającej się szkole. Artykuł stanowi kompilację refleksji odnoszącej się z jednej strony do analiz teoretycznych, a $z$ drugiej strony do praktyki edukacyjnej odzwierciedlonej w doświadczeniach zawodowych Autorki.

Słowa kluczowe: kreatywność, nauczyciel, młodzież, absolwent, rynek pracy, strategia rozwoju, edukacja, szkoła, współczesność.

\section{Wprowadzenie}

Zmieniają się radykalnie współczesne oczekiwania względem efektów pracy szkoły. Jest to związane z powszechnym zastosowaniem we wszystkich obszarach życia człowieka komputerów, z automatyzacją i robotyzacją pracy (Patrzylas 2016). Pojawia się więc potrzeba kształtowania jednostek samodzielnie, kreatywnie myślących, potrafiących posługiwać się specjalistycznymi kompetencjami, otwartych na konieczność uczestnictwa w ciągłej zmianie, akceptujących nieuchronność uczenia się przez całe życie oraz potrafiących skutecznie zarządzać procesem

\footnotetext{
* Dr Monika Christoph, adiunkt w Zakładzie Kształcenia Ustawicznego i Doradztwa Zawodowego Wydziału Studiów Edukacyjnych Uniwersytetu im. Adama Mickiewicza w Poznaniu, pedagog szkolny-doradca zawodowy w Szkole Podstawowej nr 2 im. Królowej Jadwigi w Swarzędzu, członek Polskiego Towarzystwa Pedagogicznego oraz Polskiego Towarzystwa Profesjologicznego; e-mail: monikaba@amu.edu.pl.
} 
własnego rozwoju. W związku z powyższym, szkoła jako wykazująca cechy organizacji publicznej zaspokajającej potrzeby edukacyjne odbiorców, powinna podlegać procesom ewolucji i doskonalenia w obszarach kultury organizacyjnej, sposobów zarządzania personelem, rozwoju pracowników, budowania wizji i misji oraz systemu kształcenia. Można powiedzieć, że zarysowuje się potrzeba korzystania przez szkołę z wybranych rozwiązań i metod działania organizacji prywatnych, nowoczesnych, wykazujących wysokie zdolności adaptacji i uczenia się. Warto również podkreślić, że szkoły i pracujący w niej nauczyciele podlegają pewnym prawidłowościom, podobnie jak wszelkie inne organizacje, np. te o charakterze produkcyjnym czy handlowym. Wprowadzanie zmian w szkołach staje się konieczne w obliczu istniejącej sytuacji na wirtualnym rynku edukacyjnym, gdzie ma miejsce specyficzna walka o jakość usług, pozyskanie i utrzymanie klienta, w tym przypadku ucznia (Christoph 2018, s. 187-188).

Autorka dokonała analizy raportów, literatury naukowej i branżowej, odnosząc się do własnych doświadczeń zawodowych. Pragnęła podkreślić jednocześnie, że podjęta $\mathrm{w}$ niniejszym opracowaniu problematyka, odnosząca się do zmieniającej się szkoły w kontekście wymagań rynku pracy, jest bardzo aktualna i warta zaprezentowania. Próba zarysowania wymiarów współczesnej szkoły i jej „kreatywna odsłona” w relacji do wymagań otoczenia społeczno-gospodarczego stanowią zawartość podrozdziału pierwszego. W drugiej części podjęto refleksję sytuującą szkołę w dynamicznie zmieniającej się rzeczywistości, z uwzględnieniem zagadnień związanych z gospodarką cyfrową i kompetencjami przyszłości. Kolejny podrozdział przedstawia rozważania na temat sytuacji nauczyciela w zmieniającej się szkole oraz znaczenia kreatywności w edukacji. W części końcowej artykułu wskazano na strategię zrównoważonego rozwoju w obszarze europejskim oraz w tym kontekście podkreślono potrzebę wyzwalania się nauczycieli spod systemowego nadzoru i kształtowania zintegrowanej, twórczej tożsamości zawodowej. Nawiązano również do outdoor learning concept (Klichowski 2017), którą Autorka traktuje jako podsumowującą inspirację dla zmieniającego się współcześnie oblicza szkoły.

\section{Nowoczesny wymiar współczesnej szkoły}

Główną kategorią analiz, dotyczącą stosowanych w szkole nowoczesnych metod dydaktycznych, powinny być kompetencje cyfrowe oraz te kompetencje przyszłości, które stworzą młodym ludziom możliwość odnalezienia się w tym obszarze rynku, którego głównym motorem napędzającym rozwój są wartości społeczne. „Osoby dysponujące zaawansowanymi i wyrafinowanymi umiejętnościami programistycznymi/deweloperskimi oraz statystycznymi będą stanowiły dobrze wynagradzaną elitę na rynku pracy, ale również w przypadku tych osób coraz większe znaczenie będzie miała umiejętność komplementarnej współpracy ze sztuczną inteligencją. [...] Obok wymienionych umiejętności technicznych, analizy danych, wiedzy 
przedmiotowej niezbędne będą w coraz wyższym stopniu umiejętności «mentalne wyższego rzędu", takie umiejętności, których nie osiągnie sztuczna inteligencja unikalne ludzkie zdolności poznawcze - określone podejście i sposoby myślenia o świecie; myślenie systemowe, pozwalające postrzegać rzeczy i zjawiska holistycznie i integrować ich różne funkcje; przedsiębiorczość pozwalająca wprowadzać kreatywny sposób myślenia w obszarach gospodarki i sferę społeczną; kompetencje kulturowe pozwalające działać w zróżnicowanym środowisku globalnym czy myślenie krytyczne" (Solarczyk-Ambrozik 202ob, s. 21-22). Tymczasem, jak podkreśla R. Tomaszewska (2020, s. 302), po dzień dzisiejszy w świecie obowiązuje edukacja zaprojektowana jako jednolita, liniowa seria etapów - począwszy od szkoły podstawowej, przez szkoły średnie, aż do szkół wyższych. Uczniowie nadal dzieleni są na grupy wiekowe i według tej kategorii przechodzą przez proces edukacji, a głównym miernikiem ich osiągnięć jest system ocen, wzbudzający motywację zewnętrzną wśród uczniów. Treści nauczania dzielone są na przedmioty, które uczniowie poznają oddzielnie, nie kształtując umiejętności integracji treści, o której wspominała E. Solarczyk-Ambrozik (202ob), pisząc o dużej wartości takiej integracji. Można śmiało stwierdzić, że w kulturze zależności od czynników zewnętrznych oraz w systemie klasowo-lekcyjnym zdecydowanie zniechęca się do rozwijania kreatywności i wyobraźni, zarówno w grupie nauczycieli, jak i samych uczniów. Uczenie się dzieci w grupach wiekowych zakłada, że najważniejszą cechą je łączącą jest ich data urodzenia, a nie zdolności czy predyspozycje, zainteresowania i naturalne skłonności. Marginalizowanie zasobów uczniów mieszczących się w sferze ich osobistych dążeń i rozwoju oraz skupianie się na rozdzielnej wiedzy przedmiotowej powoduje brak zaangażowania i rażąco niskie poczucie własnej wartości uczniów, którzy nie dostrzegają w sobie potencjału rozwojowego. Próbując wpasować się w sztywne ramy standardów, nie rozumieją siebie i swojej indywidualnej roli w rozwoju otoczenia - lokalnego i globalnego - nie potrafią formułować celów i nadać odpowiedni kierunek własnemu życiu1. Tradycyjny sposób organizacji szkoły i pracy nauczycieli może bardzo szkodliwie wpływać na

1 Podjęta w niniejszym rozdziale refleksja oparta została na źródłach literaturowych, a także na wiedzy i doświadczeniach Autorki tekstu, która, oprócz pracy na stanowisku naukowo-dydaktycznym na Wydziale Studiów Edukacyjnych UAM w Poznaniu, od ponad dwóch lat pracuje na stanowisku pedagoga - szkolnego doradcy zawodowego w szkole podstawowej oraz brała udział w wielu projektach edukacyjno-zawodowych, jak np. „Uczeń z pasją - kompleksowe wsparcie uczniów szkół podstawowych i gimnazjów w wyborze optymalnych ścieżek edukacyjnych i zawodowych”, współfinansowanego z EFS 2018-2019; „Nowa jakość kształcenia ogólnego w powiecie chodzieskim", w roli doradcy zawodowego dla uczniów szkół ponadpodstawowych 2018-2019; „Program szkolnego doradztwa zawodowego w gminie Tarnowo Podgórne”, prowadzonego przez Fundację Rozwoju Talentów w Poznaniu, w roli doradcy zawodowego dla uczniów szkół podstawowych 2018-2019. Autorka uczestniczyła również w projektach doskonalących kompetencje nauczycieli: Centrum Wsparcia Rzemiosła, Kształcenia Dualnego i Zawodowego w Kaliszu (2017-2018) oraz „Szkoła Ćwiczeń w Krotoszynie - Województwo Wielkopolskie”, koordynowany przez Wydział Studiów Edukacyjnych UAM Poznań (2020-2021). 
budowanie i rozwijanie postaw przedsiębiorczych, innowacyjnych. Odwołując się do Ekspertyzy - Szkoła dla innowatora (Fazlagić 2018, s. 6-7), można stwierdzić, że przedsiębiorczość to zdolność do zmiany pomysłów na działania. Trudno mówić o przedsiębiorczości, nie wspominając o innych, ściśle z nią związanych pojęciach, takich jak: kreatywność, inwencja, wytrwałość, podejmowanie ryzyka, planowanie itp. Przedsiębiorczość nie jest cechą, którą wykorzystują na swoje potrzeby wyłącznie „przedsiębiorcy”. Nowoczesne, postępowe społeczeństwa potrzebują przedsiębiorczych i kreatywnych ludzi we wszystkich obszarach funkcjonowania. W związku z tym kształcenie i wspieranie rozwoju kompetencji proinnowacyjnych powinno być priorytetem wszystkich systemów edukacji w krajach, które mają ambicje rozwoju swoich gospodarek i społeczeństw na miarę XXI wieku, także Polski. System edukacji, który wspiera przedsiębiorczość, powinien mieć następujące cechy: kształtowanie przedsiębiorczego nastawienia (entrepreneurship mindset) u młodzieży, aby stała się bardziej pewna siebie i kreatywna - bez względu na to, czy podejmie działalność gospodarczą na własny rachunek, czy podejmie pracę najemną; zachęcanie młodzieży do zakładania własnych firm, szczególnie korzystanie ze start-upów; lepsze wykorzystanie swojego potencjału na potrzeby wykonywanych ról w społeczeństwie i w gospodarce. Przykładami działań sprzyjających budowaniu kultury i polityki otwartości na innowacje i kreatywne rozwiązania są projekty Modelu Szkoły Ćwiczeń, koordynowane przez Ośrodek Rozwoju Edukacji². W dalszej części opracowania zaprezentowano przykłady dobrych praktyk dotyczące jednego z wymienionych wyżej projektów.

Projekt „Szkoła Ćwiczeń w Krotoszynie - Województwo Wielkopolskie” jest realizowany na rzecz miasta i gminy Krotoszyn od 3 sierpnia 2020 roku do 2 sierpnia 2022 roku, w ramach działania 2.10: „Wysoka jakość systemu oświaty, Programu Operacyjnego Wiedza Edukacja Rozwój 2014-2020", współfinansowanego ze środków Europejskiego Funduszu Społecznego ${ }^{3}$. Szkołą wiodącą w Gminie Krotoszyn, realizującą projekt, jest Szkoła Podstawowa nr 8 z Oddziałami Dwujęzycznymi w Krotoszynie. Do realizacji projektu Miasto i Gmina Krotoszyn pozyskała partnerów: Uniwersytet im. A. Mickiewicza w Poznaniu oraz Ośrodek Doskonalenia Nauczycieli w Kaliszu. Partnerzy posiadają odpowiedni potencjał kadrowy niezbędny do realizacji projektu, wykwalifikowaną kadrę uprawniającą do prowadzenia szkoleń, konsultacji, doradztwa zawodowego oraz warsztatów dla nauczycieli. Celem głównym projektu jest wykorzystanie potencjału Szkoły Podstawowej nr 8 w Krotoszynie, podniesienie kompetencji nauczycieli Szkoły Ćwiczeń i szkół współpracujących oraz wypracowanie metod pracy dydaktycznej rozwijających w uczniach kompetencje kluczowe. Dzięki współpracy z Uniwersytetem im. Adama Mickiewicza w Poznaniu i Ośrodkiem Doskonalenia Nauczycieli w Kaliszu kadra Szkoły Podstawowej nr 8 w Krotoszynie podnosi swoje umiejętności trenerskie

2 Zob. https://www.ore.edu.pl/2017/10/o-projekcie/ (dostęp 14.03.2021).

3 Zob. https://sp8.krotoszyn.pl/strona-4227-informacje_o_projekcie.html (dostęp 15.03.2021). 
i poznaje szerzej metody, które rozwijają w uczniach takie postawy i kompetencje, jak: kreatywność, innowacyjność, przedsiębiorczość, krytyczne myślenie, rozwiązywanie problemów, umiejętność uczenia się czy umiejętność pracy zespołowej. Przez kadrę zatrudnioną do realizacji projektu opracowywane są materiały szkoleniowe i przeprowadzany jest cykl lekcji pokazowych, szkolenia i warsztaty metodyczne, doradztwo i konsultacje na platformie e-learningowej. Odbiorcami tych działań są nauczyciele ze szkół współpracujących. W założeniu rezultatem działań sieci współpracy, skupiających nauczycieli zarówno ze szkoły wiodącej, jak i szkół współpracujących, jest i ma być w przyszłości poprawa funkcjonowania i zwiększenie wykorzystania systemu wspomagania szkół w zakresie rozwoju u uczniów kompetencji kluczowych z przedmiotów wiodących, tj. matematyki, informatyki, języków obcych oraz przedmiotów przyrodniczych. W ramach projektu technologicznie wyposażane są w szkole cztery pracownie: matematyczna, przyrodnicza, językowa i pracownia komputerowa. W Szkole Ćwiczeń organizowane są także praktyki studenckie kierunków nauczycielskich, aby w praktyce mogli oni zweryfikować teorie poznane podczas studiów oraz specyfikę działań pedagogicznych.

Współpraca z kadrą nauczycielską w ramach projektu Szkoła Ćwiczeń była ciekawym i inspirującym doświadczeniem dla Autorki tekstu. W małych zespołach odbywała się praca warsztatowa, mająca na celu realną wymianę wiedzy i doświadczeń, a także zrozumienie znaczenia osobistych przekonań określających nasz stosunek do edukacji. W wielu przypadkach tradycyjne rozumienie „misji nauczyciela" poszerza rozdźwięk między cyfrową, niejednoznaczną rzeczywistością młodzieży a formą pracy edukatorów i treścią zamkniętą szczelnie w oddzielnych przedmiotach szkolnych. Przełom roku 2020 i 2021 niezaprzeczalnie ukazał umykające tradycji, nowe oblicze edukacji i wyraźną potrzebę doskonalenia umiejętności integrowania procesów uczenia się, zarówno w perspektywie merytorycznej, metodycznej, jak i osobowościowej. W procesie dynamicznych zmian i sieciowej edukacji nauczyciele muszą zacząć od siebie i stawać się współtowarzyszami w indywidualnym rozwoju swoich uczniów. Oczywisty zdaje się fakt, że współczesny nauczyciel bardzo często staje przed pragmatycznym wyborem między szybkim i ekonomicznym sposobem przeprowadzenia lekcji metodą podającą, przekazania treści zgodnych z podstawą programową w systemie klasowo-lekcyjnym a wymogami innowacyjnej rzeczywistości, oczekiwaniami uczniów i kreatywnym sposobem realizacji zadań. System organizacji praktyk oświatowych w Polsce (w tym także awansu nauczycieli) nie sprzyja kształtowaniu pożądanej sylwetki absolwenta i zdecydowanie wymaga ze strony uczących ogromnej determinacji i samozaparcia, aby działać alternatywnie i twórczo. Pozytywnym wynikiem podjętej inicjatywy jest dostrzeżenie przez nauczycieli potrzeby zmiany form i sposobów pracy, pomimo funkcjonowania nadal w systemowo sztywnej rzeczywistości szkolnej. Nauczyciele mogą np. stosować storytelling na jednej lekcji w miesiącu, map myślowych, rozpoczynających lub podsumowujących spotkania, wykorzystanie metody projektu na zaliczenie pierwszego znaczącego działu, zamiast przeprowadzania 
sprawdzianu czy testu końcowego, lub odegranie ról i symulacje ważnych wydarzeń historycznych. Racjonalizując zagadnienie, w obecnym systemie trudno o kreatywność w pracy codziennej nauczycieli, ze względu na ograniczenia biurokratyczne, organizacyjne, sprawozdawcze i wynikające ze zwiększającej się liczby opinii o poradniach psychologiczno-pedagogicznych narzucających kompensacyjny charakter pracy z uczniem. Projekt Szkoły Ćwiczeń stanowi jednak egzemplifikację małych, powolnych, ale systematycznych zmian przede wszystkim w sposobie myślenia nauczycieli, ich pracy i w rozwijaniu „twórczej odwagi”, która w przyszłości może przerodzić się w kreatywne rytuały edukacyjne. Kreatywność i innowacyjność pojawiają się wtedy, gdy ludzie zarzucają sprawdzone scenariusze i przychodzą im do głowy nieoczywiste skojarzenia. Rytuały mogą w pewne ramy ująć chwile, gdy ludzie przełączają na bardziej kreatywne myślenie i wychodzą poza granice zwyczajności. Mogą też pomóc w budowaniu przez nauczycieli kultury uczenia stawiającej na eksperymentowanie (Ozenc, Hagan 2020, s. 68). To właśnie od niewielkich inicjatyw oddolnych i małych aktywności nauczycieli, uczniów, rodziców i innych partnerów rzeczywistości szkolnej rozpoczyna się duża zmiana, kreująca nową jakość porozumienia między szkołą - organizacją a jej dynamicznym otoczeniem.

\section{Szkoła wobec zmieniającej się rzeczywistości i wymagań rynku pracy}

Roman Schulz (1993, s. 28-29), charakteryzując poszczególne cechy szkoły rozumianej jako organizacja, wskazywał, że obserwuje się łączność i zależność między poszczególnymi jej elementami. W szkole pracuje zespół specjalistów, który może w sposób skoordynowany i skuteczny osiągać kluczowe, kształcąco-wychowawcze cele. Zarysowują się więc dwa ważne aspekty w tym względzie. Z jednej strony, odpowiednie i jakościowe przygotowanie szkoły do realizacji tak ważnego celu, a z drugiej strony - kontekst otoczenia społeczno-gospodarczego i wymagania rynku pracy.

Współczesna młodzież, kształtująca własną tożsamość w niezwykle zróżnicowanej i niejednorodnej rzeczywistości, w momentach przełomowych decyzji, dotyczących ich dalszych losów edukacyjno-zawodowych, musi wykazać się dużą samodzielnością myślenia, aktywnością i odpowiedzialnością, a także umiejętnością elastycznego i adaptacyjnego reagowania na oczekiwania kierowane pod jej adresem ze strony najbardziej kluczowych interesariuszy, jak np. rodzina, szkoła, pracodawcy, doradcy i pedagodzy. Umiejętność efektywnego wchodzenia młodych absolwentów na rynek pracy ${ }^{4}$ aktywnego kreowania własnej przyszłości zawo-

4 Tematyka sytuacji młodzieży na współczesnym rynku pracy jest aktualnie często podejmowanym i analizowanym obszarem dociekań teoretycznych i badawczych, ze względu na swoją wagę oraz potrzebę kreowania konkretnych, praktycznych rozwiązań edukacyjnych. Niniejszy podrozdział jest wynikiem refleksji formułowanej wskutek analiz literaturowych, tj. pozycji cytowanych w tekście oraz dodatkowych (Bartkowiak (Christoph 2016, s. 177; Christoph 2020a, 
dowej, a także formułowania istotnych celów życiowych powinna leżeć u podstaw określających profil absolwenta współczesnej szkoły. Ewa Solarczyk-Ambrozik (2020a, s. 264) pisze, że „W zmieniającym się świecie rośnie znaczenie zdolności adaptacyjnych jednostki do zmian, odnajdywania się w sytuacjach tranzycji, konfrontacji z niepewnością. Staranne i ostrożne planowanie w perspektywie przewidywalności zastępowane jest pojawianiem się szans, możliwości, również trudności. Decyzje odnośnie do wyboru i przebiegu kariery wzbogacone być mogą nieplanowanymi i nieprzewidywalnymi wydarzeniami i doświadczeniami. [...] Wraz ze zmianami społecznymi, ekonomicznymi, dynamicznym postępem technologicznym, indywidualizacją, następuje przesunięcie odpowiedzialności za przebieg kariery na jednostkę". Cytowana wypowiedź narzuca przekonanie, iż kształtowanie wśród młodzieży umiejętności samodzielnego, świadomego i odpowiedzialnego kreowania dróg życiowych jest bardzo istotne, zarówno z punktu widzenia ich samych, jak i oczekiwań pracodawców. Powstaje więc pytanie, czy współczesna szkoła jest władna takie kompetencje rozwijać?

Strategia rozwoju kapitału ludzkiego 2020 zakłada, że edukacja szkolna powinna być tym etapem życia, w trakcie którego nabywamy najważniejszą wiedzę i umiejętności pozwalające na satysfakcjonujące i twórcze funkcjonowanie w społeczeństwie i na rynku pracy. Na tym etapie życia kształtują się także kluczowe postawy względem siebie oraz innych ludzi, a także przekonania dotyczące zasad kształtujących współczesne środowiska pracy. Agnieszka Cybal-Michalska (2020, s. 275) wskazuje na istnienie zależności między proaktywną i prorozwojową postawą młodzieży a doświadczaniem sukcesu życiowego i edukacyjnego. Absolwentka i absolwent współczesnej szkoły charakteryzujący się proaktywnością to osoba posiadająca autentyczną elastyczność poznawczą, wizję dobrostanu, który pragnie osiągnąć $\mathrm{w}$ przyszłości oraz silne poczucie sprawstwa, wynikające $\mathrm{z}$ motywacji wewnętrznej. Tak ukształtowane przekonania wśród młodych ludzi zwiększają szanse na efektywne poruszanie się ich po dynamicznym rynku pracy i samorealizację w życiu osobistym. System edukacyjny, ze względu na swoją powszechność, stanowi więc naturalny mechanizm pozwalający identyfikować i wspierać rozwój osób o największym potencjale, a jednocześnie daje możliwość wyrównywania szans już na wczesnym etapie życia. Priorytetem staje się jakość nauczania, także stosowanie nowoczesnych metod dydaktycznych odnoszących się do aktywności i podmiotowości jednostki oraz jakość kompetencji uzyskiwanych w szkole przez młodych ludzi. Renata Tomaszewska (2020, s. 306) stwierdza, że podstawowymi wyznacznikami dla zmian w oświacie powinny być, po pierwsze, większe wsparcie i rozwój uczniów o wybitnym potencjale przy jednoczesnym dalszym zmniejszaniu liczby uczniów osiągających najsłabsze wyniki. Aktualnie należy intensywnie inwestować w kompetencje nauczycieli do pracy z uczniem zdolnym oraz wyposażać

s. 191; Christoph 202ob, s. 279; Cybal-Michalska 2016, s. 59; Kozielska 2020, s. 365; Pyżalski 2020; Solarczyk-Ambrozik 2018, s. 19; Wawrzonek 2018, s. 99; Wołk 2013, s. 239). 
ich w konkretne narzędzia i scenariusze, gdyż obszar ten wyraźnie kuleje. Zauważa się nie tylko braki w kompetencjach, narzędziach czy stosowanych metodach, ale także niedomagania w systemie organizacyjno-czasowym szkoły i samych chęciach nauczycieli. Eugeniusz Piotrowski, odnosząc się do zagadnienia wspomagania uczniów zdolnych, jako istotnego warunku postępu społecznego, stwierdza, że „to jednostki zdolne potrafią lepiej zrozumieć rosnącą złożoność zjawisk światowych i zredukować uczucie niepewności, jakie ona niesie. Posiadając szerszą i lepszą wiedzę o świecie, potrafią także lepiej zrozumieć siebie i innych. Wzmożone zainteresowanie tą grupą uczniów znajduje wyraz w licznych publikacjach, a także powstawaniu instytucji badawczych, których działalność zmierza w kierunku koordynacji badań, zbierania i udostępniania informacji oraz doskonalenia pracy nauczycieli. [...] Z dużym uznaniem trzeba przyjąć fakt, że w większości krajów europejskich, także w Polsce, w coraz większym stopniu zaczyna się respektować różnice indywidualne wśród uczniów" (Piotrowski 2020, s. 26). Takie podejście koresponduje $\mathrm{z}$ drugim postulatem zmian w oświacie, $\mathrm{w}$ ramach którego R. Tomaszewska podkreśla konieczność wzmacniania kluczowych kompetencji młodzieży, a także rozwijania ich różnorodności, przedsiębiorczości, kreatywności i zdolności do samodzielnego uczenia się na wszystkich etapach szkolnych. Po trzecie, w programach kształcenia niezbędna jest obecność pracodawców jako praktyków kreujących rynek pracy. Trudno nie zgodzić się z faktem, że to właśnie otoczenie społeczno-gospodarcze oraz przedsiębiorcy są najbardziej wiarygodnym źródłem wiedzy o zapotrzebowaniu na kwalifikacje w krótko- i długookresowej perspektywie. W czasach intensywnej cyfryzacji środowisk pracy zarysowuje się więc wyraźna potrzeba budowania i rozwijania kompetencji absolwentów odpowiadających aktualnym i przewidywanym potrzebom. Głównym zadaniem stawianym przez współczesną szkołę jest nie tylko nauczanie tego, jak używać wiedzy, ale także jak ją tworzyć. Dlatego zhierarchizowany model edukacji, zakładający dyscyplinę i konformizm ze strony ucznia, oraz koncepcja liniowego przechodzenia przez kolejne etapy systemu w celu wejścia na rynek pracy, gdzie pracuje się przez całe życie w jednym zawodzie, zdecydowanie nie odpowiada ani potrzebom uczniów, ani oczekiwaniom pracodawców. Warto więc pochylić się nad pytaniem, jakie kompetencje przyszłości powinny cechować współczesnego absolwenta szkoły?

Renata Włoch i Katarzyna Śledziewska (2020, s. 158) w swojej publikacji dotyczącej gospodarki cyfrowej zastanawiają się, jak zmieni ona świat i funkcjonowanie człowieka w konkretnych obszarach życia, także w edukacji i pracy. Z całą pewnością, za Natalią Hatalską (2016a, s. 17-22), przewiduje się powstanie grupy społecznej tzw. the useless class, czyli ludzi, którzy nie będą potrafili podążać za nowoczesnymi technologiami i nie będą elastyczni poznawczo, choćby na tyle, żeby odnaleźć nowe, alternatywne role edukacyjno-zawodowe. Dlatego zgodnie z założeniami R. Włoch oraz K. Śledziewskiej, na rynku pracy oprócz kompetencji cyfrowych znaczenia nabiorą kompetencje przynależne tylko człowiekowi, odróżniające jego pracę od robotów i sztucznej inteligencji. W tym kontekście warto 
mówić o kompetencjach, które są rozumiane szerzej i wiążą się z wykształceniem określonych postaw, sposobów myślenia, uczenia się i działania, niż o konkretnych, wyuczonych umiejętnościach, które w obliczu dynamiki rynkowej szybko się dezaktualizują i ulegają modyfikacjom. Zgodnie z raportem Pracownik przyszłości..., pokolenie Z, czyli dzisiejsi 2o-latkowie, to pokolenie, które dopiero wchodzi w dorosłość, zatem trudno jednoznacznie wskazywać na ich kompetencje. Niewątpliwie są to osoby, które łączą świat wirtualny z realnym - Twitter zastępuje im codzienną prasę, komunikują się przy pomocą Snapchata, zdjęcia i filmy oglądają na Instagramie lub Tik Tok-u, wiedzę czerpią z Wikipedii. To zapewne jest różnica między tym pokoleniem a pokoleniami znacznie starszymi. Jednak należy pamiętać, że mimo funkcjonowania w cyfrowym świecie mają potrzebę kontaktów i spotkań bezpośrednich. Lubią rozmawiać ze swoimi przełożonymi o sprawach, które są dla nich ważne i cenią sobie bezpośrednie relacje. Jeśli zaś chodzi o kompetencje, badania (Hatalska, Trapp 2019) wskazują, że jest to pokolenie, dla którego ważna jest niezależność (częściej, niż ich poprzednicy wskazują na chęć posiadania własnej działalności). Są oni otwarci na zmiany i łatwo adaptują się do nowych sytuacji. Zdecydowana większość chce, aby praca była ich pasją. Ważne są dla nich też nowe doświadczenia i samorozwój. Nie chcą już często spędzać tradycyjnie ośmiu godzin za biurkiem, jak ich rodzice, ale chcą mieć możliwość pracy zdalnej, podróży. Warto na pewno też bliżej przyjrzeć się w tym kontekście zjawisku cyfrowego nomadyzmu, czyli coraz większej grupie osób, która łączy pracę z podróżami i zbieraniem doświadczeń (Hatalska 2016b, s. 8-37). Analizując powyższe rozważania, można zauważyć silnie wyodrębniającą się potrzebę niezależności i wolności jednostek, widoczną zarówno w sferze edukacji, jak i pracy zawodowej. Pasja, podróże, nowoczesne technologie oraz samodzielne i efektywne zarządzanie czasem stały się współcześnie synonimem zindywidualizowanego typu kariery pokolenia $\mathrm{Z}$ i jednocześnie swoistym zestawem kompetencyjnym, oczekiwanym przez współczesnych pracodawców.

Podsumowując rozważania zawarte w niniejszym podrozdziale, warto zwrócić uwagę na zależność, jaka powstaje między aktualnymi i przyszłymi scenariuszami pracy, kompetencyjnym zestawem oczekiwań formułowanym ze strony pracodawców a kierunkami działań i rozwoju współczesnej szkoły oraz profilem jej absolwentów. Jak podkreśla Stefan M. Kwiatkowski, pojęcie kompetencji przyszłości odnosi się do dających się przewidzieć kierunków zmian cywilizacyjnych, które będą dotyczyły wszystkich sfer życia. Chociaż przewidywanie ich w dłużej perspektywie nie sprawdzi się, to jednak „myślenie o kompetencjach przyszłości ma głęboki sens edukacyjny - pozwala odpowiednio projektować proces kształcenia, ale też uzmysławia uczniom potrzebę ciągłego uczenia się, autonomicznego i odpowiedzialnego reagowania na dynamicznie zmieniającą się sytuację" (Kwiatkowski 2018, s. 23). 


\section{Nauczyciel w zmieniającej się szkole - kształtowanie twórczej odwagi}

Trudno nie zgodzić się ze stwierdzeniem, że do kluczowych zadań nauczyciela należy rozwijanie zdolności twórczych uczniów, kształtowanie umiejętności nieszablonowego myślenia, inicjowanie działań sprzyjających otwartości na to, co nowe oraz rozwijające kreatywność. Jednakże wielu specjalistów w sferze edukacji, choć przekonanych o wadze powyższych zadań, nie realizuje ich w praktyce i osobiście nie odczuwa za nie odpowiedzialności. Nauczycielom brakuje wiedzy na temat twórczości, nie potrafią prawidłowo scharakteryzować sylwetki ucznia kreatywnego, mają problem z przeprowadzeniem diagnozy zdolności i uzdolnień twórczych, odznaczają się niskim poziomem kompetencji umożliwiających stymulowanie kreatywności swoich uczniów. T. Parczewska oraz I. Zwierzchowska (2017, s. 39) podkreślają więc, że zdecydowanie konieczna jest zmiana myślenia o roli kreatywności w rozwoju ucznia i idąca za tym zmiana paradygmatu szkoły. Już w 2009 roku Bogusław Śliwerski (s. 320) wskazywał, że „najważniejszą rolą szkoły XXI w. będzie rozwijanie samodzielności, aktywności, innowacyjności i różnych technik komunikowania się”. Człowiek „globalnej wioski” będzie w dużej mierze pracował bardziej samodzielnie niż dotychczas, ale z pomocą najnowszych urządzeń informacyjnych. Można zakładać, że reformy oświatowe będą przebiegać dwutorowo. $Z$ jednej strony, nastąpią próby doskonalenia tradycyjnej szkoły w wyniku odchodzenia od współzawodnictwa jako motorów procesów nauczania i uczenia się na rzecz współpracy i współdziałania grup rówieśników w klasie szkolnej, którzy będą interpretować i tworzyć własną wiedzę. Bierne asymilowanie wiedzy zejdzie na drugi plan. Uczniowie staną się autentycznymi podmiotami procesów uczenia się. Rola nauczyciela będzie się coraz bardziej ograniczać do ułatwiania dzieciom i młodzieży uczenia się w wyniku dynamicznych procesów gromadzenia, przetwarzania i stosowania wiedzy. Z drugiej strony, można liczyć się z powstaniem alternatywy wobec tradycyjnego modelu oświaty w postaci szkoły wirtualnej, która może okazać się bardziej przydatna tym, którzy będą mogli i chcieli uczyć się na odległość”. „Mija właśnie rok, odkąd świat wstrzymał oddech we wszelkich aspektach życia: ekonomicznym, społecznym, kulturowym, ale także w odniesieniu do poszczególnych szczebli edukacji” - pisze Mariusz Przybyła (2020, s. 211-212). Dotychczas silnie nacechowana nowymi technologiami informacyjno-komunikacyjnymi codzienność domagała się dla zdalnych form w obrębie edukacji na poziomie podstawowym, ponadpodstawowym i wyższym. Stajemy aktualnie w obliczu głębokich zmian, chwiejących podstawami współczesnej edukacji, znacznie przyspieszonej w swym wirtualnym rozwoju. Aby sprostać wyzwaniom edukacyjnym stojącym przed uczącymi się i nauczającymi, które zakładają kształtowanie człowieka, bardzo istotna wydaje się świadomość tych zmian wśród pedagogów i nauczycieli. M. Przybyła (2020, s. 213) podkreśla, że „to, co jest naprawdę ważne w kształceniu, to empatia i umiejętność odpowiedniego odnoszenia się do wychowanków/podopiecznych/uczniów. Technologie wspierają 
dzisiejszego pedagoga, choć należy pamiętać, że narzędzia te ulegają nieustannym zmianom, dezaktualizacjom zarówno w obrębie soft-, jak i hardware. Ów "partner» wymaga ciągłej czujności ze strony nauczyciela kształcącego nowe pokolenie". Czujność ta przejawiać się może w realnej otwartości na zmianę, elastyczności poznawczej, adaptacyjnych strategiach działania oraz w rozwijaniu kreatywnych technik pracy.

Problematyka kreatywności w pracy nauczycieli jest współcześnie bardzo aktualna, ciekawa i istotna w kontekście dokonywania kolejnych eksploracji badawczych oraz potrzeb sektora edukacji. Samo zainteresowanie kreatywnością można wytłumaczyć m.in. tym, że stanowi ona konieczny atrybut bycia w świecie człowieka nowoczesnego, pracownika przyszłości. Współczesny, dynamicznie zmieniający się we wszystkich sferach życia człowieka świat, z jednej strony wzbudza niepokój, wprowadzając brak równowagi, dysharmonię i zakłócając dotychczasowe przyzwyczajenia, czy wzorce zachowań, a z drugiej - uaktywnia, motywuje i rozwija, stawiając przed jednostką różnorodne, nietypowe wyzwania, którym może sprostać wyłącznie ktoś myślący w sposób nieszablonowy, nowatorski, sytuujący się poza schematem.

Warto w tym miejscu zastanowić nad sposobem rozumienia samej kreatywności. Zazwyczaj w pierwszym odruchu kojarzy nam się z obszarem przedsięwzięć artystycznych - rzeźby, rysunku, muzyki i tańca. Jednak twórcze myślenie, kreatywność to pojęcia dużo szersze i bardziej uniwersalne. Za twórcze myślenie uważa się wykorzystywanie wyobraźni do stworzenia czegoś nowego, czego świat jeszcze nie widział. Kreatywność pojawia się wtedy, gdy człowiek ma szansę wskazania na własne, nowe pomysły, rozwiązania i założenia oraz wykazuje determinację do udostępnienia tych zasobów innym. Jak podaje Słownik pedagogiczny, „kreatywnością jest cecha określająca człowieka twórczego, autora oryginalnych dzieł teoretycznych lub/i praktycznych, wynalazcę" (Kupisiewicz, Kupisiewicz 2009, s. 86). Krzysztof J. Szmidt (2010, s. 8; 2013, s. 83) twierdzi, że kreatywność to właściwość charakteru (postawy) człowieka, zdolność generowania nowych, a jednocześnie wartościowych pomysłów (rzeczy, koncepcji, idei, rozwiązań). Podkreśla on, że kreatywny jest człowiek, a nie pewien wytwór czy produkt. Istotą kreatywności jest pomysłowość - idea, wizja, czyli zdolność do wytwarzania wielu pomysłów zmierzających do rozwiązania problemów otwartych. Z kolei Ken Robinson (2010, s. 151) w swoich rozważaniach odnoszących się do kreatywności podkreśla jej wytwór, twierdząc, że „oryginalność sugeruje, że rezultaty są nowe. Kreatywnością jest pełen wyobraźni proces, którego skutki są oryginalne”. W opinii K. Robinsona kreatywny rezultat może być nietypowy na różnych poziomach: dla pojedynczej osoby zaangażowanej będzie to oryginalność osobista; dla konkretnej społeczności - oryginalność społeczna, natomiast w wymiarze całej ludzkości możemy mówić o oryginalności historycznej. W myśl takiego rozumienia kreatywności to unikatowość, wyjątkowość ostatecznego rezultatu czy dzieła liczy się jako miernik wykazywanej przez człowieka aktywności. W świecie biznesu kreatywność objawia 
się jako innowacja. Rzeczywistość permanentnej zmiany społeczno-gospodarczej silnie narzuca wymaganie dotyczące kształtowania umiejętności przetwarzania idei, pomysłów i nowych rozwiązań w praktyczne zastosowania. $Z$ całą pewnością elastyczność poznawcza, otwartość na zmianę i oryginalność strategii radzenia sobie z wyzwaniami stanowią kluczowy komplet kompetencji oczekiwanych od młodych ludzi, zarówno w świecie edukacji, jak i dokonań zawodowych. Autorki Teresa Parczewska i Iwona Zwierzchowska (2017, s. 22) zwracają uwagę na koncepcję pankreacjonizmu, obejmującego w XX wieku wszystkie dziedziny działalności ludzkiej i zakładającego, że potencjał twórczy przypisany jest każdej jednostce, bez względu na to, czy jest wybitnie uzdolniona, czy nie. Źródło tej koncepcji tkwi w teoriach zakładających, że twórczość jest pierwotną potrzebą człowieka, która wynika $\mathrm{z}$ dążenia do samorealizacji. Pojęcie twórczości zostało zastąpione określeniem kreatywność, które może oznaczać wszystko, począwszy od kreatywnego myślenia, poprzez kreatywne zarządzanie, do kreatywnego nauczania czy wychowania. Powszechność pojęcia kreatywności również podkreśla Wiesława Limont (2003, s. 18) stwierdzając, że „koncepcja twórczości codziennej pozwala uznać za twórcze każde rozwiązywanie zadania, każdy przejaw aktywności, która w minimalnym nawet stopniu zmienia zastaną sytuację wewnętrzną lub zewnętrzną. Koncepcja ta przesuwa także punkt ciężkości z cechy wytworu na wewnętrzną aktywność podmiotu". Można śmiało stwierdzić, że właśnie na takiej aktywności jednostki, dążącej do samorealizacji i aktywnej kreacji, zależy współczesnym pracodawcom, którzy szczególnie wśród młodych ludzi poszukują odwagi i otwartości. Autorzy książki Twórcza odwaga. Otwórz się na design thinking Tom Kelley i David Kelley (2019, s. 22-23) stwierdzają: „Nasze doświadczenie pokazuje, że każdy jest twórczym typem. (...) Twórcza odwaga jest sposobem doświadczania świata, z którego biorą się nowe podejścia i nowe rozwiązania. Wiemy, że każdy może posiąść twórczą śmiałość. Spotykaliśmy wielu ludzi różnych zawodów i na różnym etapie kariery. Każdy - od naukowców w laboratoriach po menedżerów najwyższego szczebla - może inaczej podejść do życia, inaczej na nie spojrzeć i zyskać większy zasób środków i narzędzi. Ta różnorodność perspektyw sprawia, że każda jednostka tworzy swój unikatowy kapitał, poszukuje możliwości wszechstronnego rozwoju podkreślającego jej wyjątkowość, a w przełożeniu na praktyczną aktywność życiową, formułuje określoną ofertę edukacyjno-zawodową dla współczesnych pracodawców. Oczywiste jest, że w procesie tym w wielu przypadkach pomocą służą doradcy zawodowi, coachowie kariery, nauczyciele, wychowawcy, a także najbliżsi opiekunowie, rodzice. Jednostka stojąca w obliczu niezwykłej różnorodności i sfragmentaryzowania otoczenia społeczno-gospodarczego często odczuwa zagubienie i brak kompetencji decyzyjnych. Dlatego doradztwo edukacyjno-zawodowe powinno skupiać się na wskazywaniu obszarów kompetencji, które są rozwinięte oraz tych, nad którymi należy pracować, wskazać możliwości ich rozwoju lub udoskonalenia tak, aby jednostka czuła się komfortowo, zarówno sama ze sobą, jak i w otaczającej ją rzeczywistości. Odnosząc się do zagadnień kompetencji pracownika przyszłości 
oraz sytuacji młodych na współczesnym rynku pracy, podjętych w części drugiej niniejszego artykułu, warto zaprezentować kluczowe kierunki rozwoju praktyki doradztwa edukacyjno-zawodowego dla młodzieży. Magdalena Barańska (2020, s. 246-247) stwierdza, że doradztwo edukacyjno-zawodowe powinno być ukierunkowane na promowanie idei całożyciowego uczenia się, a także równorzędności form, sposobów i miejsc uczenia się. Pozwali to młodzieży na kształtowanie realnej postawy otwartości na zmiany i akceptacji niestabilności otoczenia. Korzystanie z profesjonalnej pomocy w urzeczywistnieniu swojego kreatywnego potencjału edukacyjnego powinno nosić znamiona świadomego i indywidualnego wyboru jednostki. Niewątpliwie wzmacnia to poczucie sprawstwa, które jest niezwykle ważne w konstruowaniu ścieżek edukacyjno-zawodowych. M. Barańska podkreśla także rolę doradztwa w procesie uznawalności efektów uczenia się zdobytych poza formalnym systemem kształcenia. Współcześnie korzysta się w procesie edukacji z różnych form edukacji, coraz częściej krótkich, i za pomocą różnych metod, źródeł - tych tradycyjnych i zdalnych. Doradztwo edukacyjno-zawodowe powinno być także ogniwem łączącym sektor pracy z sektorem edukacji, co uważa się za niezwykle potrzebną perspektywę. Jedynie mając realne rozeznanie w oczekiwaniach rynku pracy oraz uwarunkowaniach współczesnych środowisk zawodowych, specjaliści, jak np. doradcy zawodowi, nauczyciele, edukatorzy, są w stanie efektywnie wspierać młodych ludzi w kształtowaniu ich ścieżek życiowych. Ważnym więc jest, aby w pracy z młodzieżą korzystać z metod aktualnych, kreatywnych i otwierających pełne możliwości samorealizowania się młodzieży, zarówno w obszarze szkolnym, jak i poza nim.

\section{Podsumowanie - inspiracje dla zmieniającej się szkoły}

Analiza zjawisk oświatowych z całą pewnością nie może dokonywać się jedynie z jednej perspektywy, lecz powinna być osadzona w szerokim i zróżnicowanym kontekście, poczynając od ogółu zjawisk aż po szczegółową metodykę pracy nauczycieli i ich doświadczenia w codzienności szkolnej. Odnosząc się do ogółu, warto przytoczyć trzy główne priorytety sformułowane w Strategii na rzecz inteligentnego i zrównoważonego rozwoju sprzyjajacego właczeniu społecznemu. Europa 2020 (Bruksela, 3.03.2010), związane ze zmianami, jakich doświadcza Europa i z jakimi będzie się mierzyła w przyszłości. Strategia podkreśla rolę procesu uczenia się przez całe życie dla wzmocnienia gospodarki i spójności społecznej Europy. Obejmuje trzy bardzo istotne i wzajemnie powiązane priorytety, jakimi są: rozwój gospodarki opartej na wiedzy i innowacji - rozwój inteligentny; rozwój zrównoważony - wspieranie gospodarki efektywniej wykorzystującej zasoby, bardziej przyjaznej środowisku i bardziej konkurencyjnej; rozwój sprzyjający włączeniu społecznemu, czyli wspieranie gospodarki o wysokim poziomie zatrudnienia, zapewniającej spójność społeczną i terytorialną. W kontekście powyższych założeń, E. Solarczyk-Ambrozik (2013, s. 23) stwierdza, że lepsze wykształcenie przekłada się na większe szanse na 
rynku pracy, a zwiększenie stopy zatrudnienia przyczynia się do zmniejszenia ubóstwa. Strategia zakłada, że inteligentny rozwój oznacza zwiększenie roli wiedzy i innowacji, jako sił napędowych przyszłego rozwoju. Działania, jakie należy podjąć, to m.in. kształcenie, szkolenie i uczenie się przez całe życie. Oznacza to, jak pisze dalej E. Solarczyk-Ambrozik, że państwa członkowskie będą musiały zapewnić odpowiedni poziom inwestycji w systemy szkolenia i kształcenia na wszystkich poziomach, poprawić - z uwzględnieniem kompetencji kluczowych - rezultaty procesu kształcenia, zwiększyć otwartość i znaczenie systemów kształcenia poprzez utworzenie krajowej struktury kwalifikacji i lepsze łączenie procesu kształcenia z potrzebami rynku pracy.

Trudno nie zgodzić się więc ze stwierdzeniem, że powinno istnieć silne powiązanie między tym, co dzieje w otoczeniu społecznym i gospodarce cyfrowej, oraz tym, w jaki sposób szkoła rozwija kompetencje nauczycieli w zakresie przygotowania uczniów do przejścia na dalszy etap edukacyjny i w konsekwencji zawodowy. Pożądanym kierunkiem działań dla współczesnej szkoły jest odchodzenie od silnego skupienia na treściach przedmiotowych i w warunkach spełniania wytycznych wynikających z podstawy programowej, rozwijanie alternatywnych, aktywizujących sposób przekazywania wiedzy, jak np. metody projektowe, mapy myślowe, storytelling, symulacje, dramy, coaching. Takie podejście pozwala na kształtowanie wśród uczniów inicjatyw oddolnych, zwiększa poczucie własnej wartości i wzmacnia postawy przedsiębiorcze. Jak wskazuje A. Cybal-Michalska (2014, s. 93-94), proaktywność młodzieży jest aktualnie cechą niezwykle pożądaną na rynku edukacyjno-zawodowym, a jak już wcześniej wspomniano, poprzez ograniczenia systemowe i koncentrację na metodach podających, nie charakteryzuje profilu współczesnego absolwenta. Cytując za B. Śliwerskim (2013, s. 48-49), „nie jest jednak łatwo uwolnić się nauczycielowi w systemie edukacji państwowej, w której tak wiele mu przeszkadza. Ideologia i praktyka silnej władzy państwowej ogranicza wolność wszystkich tych, którzy zajmują stanowiska w instytucjach państwowych, a do takich należą m.in. nauczyciele. [...] Pojawienie się w strukturze oświaty państwowej suwerennego nauczyciela nie spotyka się z pełną aprobatą nawet przez tych przedstawicieli władz edukacyjnych, którzy optują za głęboką, oddolną reformą szkolną". W odniesieniu do powyższych faktów można stwierdzić, że rolą nauczyciela jest jednak wyzwalanie, zdobywanie i utrwalanie wolności w wyborze i realizacji założonych celów, która sama w sobie będzie zdolnością do samostanowienia i podążania za zmieniającą się rzeczywistością szkolną. Śliwerski (2013, s. 51) podkreśla, że nauczyciele „powinni zerwać $\mathrm{z}$ «nadawaną» przez władzę tożsamością roli zawodowej na rzecz tożsamości «zadanej», skłaniającej ich do twórczych poszukiwań, do samookreślenia i samostanowienia”. W sytuacji, gdy sami nauczyciele nie czują się autonomicznymi, indywidualnymi i twórczymi podmiotami środowiska szkolnego, ich postawa rzutuje na uczniów i wychowanków, tworząc raczej konformistyczny fundament. Odnosząc się do analogii pracy i tożsamości naukowca, warto w podsumowaniu wskazać słowa Zbyszko Melosika 
(2018, s. 19), który podkreślał, że rdzeń pasji zawodowej znajduje się w tożsamości osobistej każdego nauczyciela, jest to stan serca i umysłu, który można zachować niezależnie od okoliczności i barier zewnętrznych. To właśnie pasja, a nie obowiązek może być źródłem wolności i władzy w zakresie konstruowania kreatywnego wymiaru tożsamości zawodowej nauczycieli w zmieniającej się rzeczywistości szkolnej.

Jak podkreśla autorka, oczywisty zdaje się fakt, iż relacja zależności między szkołą rozumianą jako organizacja i jej formalnym uporządkowaniem a kadrą pracowniczą, jaką są nauczyciele, jest obustronna, wzajemna. Szkoła i jej przywódcy mogą kreować atmosferę współpracy i dzielenia się doświadczeniami oraz kulturę sprzyjającą innowacji i myśleniu przedsiębiorczemu, ale to nauczyciele ponoszą osobistą odpowiedzialność za jakość podejmowanych działań w klasie i umiejętność kształtowania wśród uczniów pożądanych postaw społeczno-zawodowych. Podobnie w drugą stronę patrząc, nawet najbardziej twórczy i aktywny zespół nauczycielski często nie jest w stanie przebić skostniałej struktury szkolnej kierowanej przez klasycznego autokratę (Kwiatkowki 2011, s. 17). Rzeczywistość społeczno-gospodarcza i rynek pracy w Polsce bardzo dynamicznie się zmieniają i rozwijają w ostatnich latach, za czym „rzeczywistość szkolna” nie jest w stanie nadążyć ani spełnić oczekiwań dotyczących pożądanej jakości. Jak już wspomniano w podrozdziale charakteryzującym nowoczesny wymiar szkoły, możliwe są działania bezpośrednio zmieniające metody i charakter pracy nauczycieli oraz ze strony dyrekcji, tworzenie atmosfery sprzyjającej myśleniu innowacyjnemu i przyszłościowemu. Być może wyzwaniem i inspiracją dla zmieniającej się szkoły w przyszłości będzie upowszechnienie idei edukacji na zewnątrz (outdoor education), która jak pisze Michał Klichowski (2017, s. 97-99), znana już była od czasów Arystotelesa. Autor wskazuje na pięć kluczowych czynników odróżniających edukację outdoorową od tej tradycyjnej, klasowo-lekcyjnej: 1. Tworzenie naturalnego środowiska uczenia się i poznawania rzeczywistości; 2. Uczniowie nie tylko opuszczają mury szkoły, ale także wychodzą poza znaną sobie i bezpieczną strefę komfortu; 3. Kładzie się nacisk na spontaniczność uczniów w odniesieniu do realnych zdarzeń; 4. Uczniowie wchodzą w role odkrywców i ekspertów, którzy mają szansę na samodzielne zweryfikowanie swoich pasji i zainteresowań; 5 . Uczniowie zachęcani są do wyrażania własnych opinii oraz krytycznej refleksji w odniesieniu zarówno do metod, form i źródeł uczenia się, jak i względem otoczenia. Wyraźnie zarysowuje się zależność między wymienionymi wyżej czynnikami a wymaganiami zmieniającej się rzeczywistości i dynamiką rynku pracy. Cytując M. Klichowskiego (2017, s. 99): „Edukacja outdoorowa zakłada częściowe przeniesienie procesu uczenia się na zewnątrz, $\mathrm{z}$ dala od instytucji edukacyjnych do miejsc bliskich naturze. To nie muszą być jedynie obszary lasów, gór czy innych krajobrazów naturalnych. To mogą być parki (cyberpraki), w których różnorodne elementy edukacji mogą być wykorzystywane i eksplorowane. To jest kontekst, w którym pojawia się koncepcja uczenia się na zewnątrz (outdoor learning concept)" (tłum. własne). Wykorzystując założenia edukacji zewnętrznej, szkoła może kształtować realne i pożądane współcześnie 
kompetencje absolwentów, a tym samym efektywniej adaptować się do zmieniającej się rzeczywistości.

\section{Bibliografia}

Barańska M. (2020). Scenariusze przyszłości pracy jako katalizator zmian w obszarze doradztwa. W: Edukacja dorosłych a planowanie karier edukacyjno-zawodowych. Solarczyk-Ambrozik E., Christoph M., Konieczna-Woźniak R. (red.). Poznań: Wydawnictwo Naukowe UAM.

Bartkowiak (Christoph) M. (2016). Sytuacja zawodowa $i$ wartość pracy w życiu współczesnej młodzieży. W: Doradztwo zawodowe w perspektywie całożyciowego uczenia się. Solarczyk-Ambrozik E. (red.). Poznań: Wydawnictwo Naukowe UAM.

Christoph M. (2018). Szkoła jako organizacja uczaca się. W: Solarczyk-Ambrozik E., Barańska M. (red.). Poznań: Wydawnictwo Naukowe UAM.

Christoph M. (2020a). Pracownik a pracodawca. Budowanie dwustronnej relacji w kontekście zmian na rynku pracy. W: Edukacja dorostych a planowanie karier edukacyjno-zawodowych. Solarczyk-Ambrozik E., Christoph M., Konieczna-Woźniak R. (red.). Poznań: Wydawnictwo Naukowe UAM.

Christoph M. (2020b). Młodzi na rynku pracy, czyli kogo chca zatrudniać wspótcześni pracodawcy? W: Społeczno-edukacyjny potencjał szkoły a rynek pracy. Christoph M., Wawrzyniak S. (red.). Poznań: Wydawnictwo Naukowe UAM.

Cybal-Michalska A. (2014). Proaktywność w karierze jako narzędzie inwestycji i odnawialności kapitału kariery młodzieży akademickiej. „Rocznik Pedagogiczny”, nr 37.

Cybal-Michalska A. (2016). Sukces w karierze jako wynik doświadczeń podmiotu $w$ przebiegu pracy zawodowej. W: Doradztwo zawodowe w perspektywie całożyciowego uczenia się. Solarczyk-Ambrozik E. (red.). Poznań: Wydawnictwo Naukowe UAM.

Cybal-Michalska A. (2020). Proaktywność jako strategia doświadczania sukcesu $w$ karierze. W: Społeczno-edukacyjny potencjał szkoły a rynek pracy. Christoph M., Wawrzyniak S. (red.). Poznań: Wydawnictwo Naukowe UAM.

Edukacja w czasach pandemii wirusa COVID-19. Z dystansem o tym, co robimy obecnie jako nauczyciele (2020). Pyżalski J. (red.). Warszawa: EduAkcja.

Fazlagić J. (2018). Ekspertyza. Szkoła dla innowatora. Kształtowanie kompetencji proinnowacyjnych. Kalisz: Ośrodek Doskonalenia Nauczycieli.

Hatalska N. (2016a). Raport. Praca: scenariusze przyszłości. Warszawa: Infuture Hatalska Foresight Institute.

Hatalska N. (2016b). Raport o wspótczesnych nomadach. Warszawa: Infuture Foresight Institute.

Hatalska N., Trapp A. (2019). Raport. Pracownik przyszłości. Warszawa: Infuture Hatalska Foresight Institute. 
Kelley T., Kelley D. (2019). Twórcza odwaga. Otwórz się na design thinking. Warszawa: MT Biznes.

Klichowski M. (2017). Learning in cyberparks. A theoretical and empirical study. Poznań: Wydawnictwo Naukowe UAM.

Kozielska A. (2020). Tranzycja ze szkoły uczącej zawodu na rynek pracy w kontekście kompetencji przyszłości i scenariuszy przyszłości rynku pracy. W: Społecznoedukacyjny potencjał szkoły a rynek pracy. Christoph M., Wawrzyniak S. (red.). Poznań: Wydawnictwo Naukowe UAM.

Kupisiewicz C., Kupisiewicz M. (2009). Słownik pedagogiczny. Warszawa: Wydawnictwo Naukowe PWN.

Kwiatkowki S.M. (2011). Typologie przywództwa. W: Przywództwo edukacyjne w szkole i jej otoczeniu. Kwiatkowski S.M., Michalak J.M., Nowosad I. (red.). Warszawa: Difin.

Kwiatkowski S.M. (2018). Kompetencje przyszłości. Warszawa: Wydawnictwo FRSE.

Limont W. (2003). Twórczość w aspekcie cyklu życia. W: Twórczość - wyzwanie XXI wieku. Dombrowska E., Niedźwiedzka A. (red.). Kraków: Oficyna Wydawnicza "Impuls".

Melosik Z. (2018). Pasja i tożsamość naukowca. „Rocznik Pedagogiczny”, nr 41.

Ozenc K., Hagan M. (2020). Kreatywne rytuaty przydatne w pracy. Warszawa: Wydawnictwo MT Biznes.

Parczewska T., Zwierzchowska I. (2017). Swoistość postrzegania kreatywności. W: Kreatywność jako wymiar profesjonalizacji przyszłych nauczycieli wczesnej edukacji. Bałachowicz J., Adamek I. (red.). Warszawa: Wydawnictwo Akademii Pedagogiki Specjalnej.

Piotrowski E. (2020). Wspomaganie rozwoju uczniów zdolnych jako ważny warunek postępu społecznego. W: Społeczno-edukacyjny potencjał szkoły a rynek pracy. Christoph M., Wawrzyniak S. (red.). Poznań: Wydawnictwo Naukowe UAM.

Przybyła M. (2020), Szkoła „złowiona” we własne sieci - rzecz o kształceniu tradycyjnym i komplementarnym. W: Społeczno-edukacyjny potencjał szkoły a rynek pracy. Christoph M., Wawrzyniak S. (red.). Poznań: Wydawnictwo Naukowe UAM.

Robinson K. (2010). Oblicza umystu. Ucząc się kreatywności. Kraków: Wydawnictwo Element.

Schulz R. (1993). Szkoła jak organizacja. Toruń: Wydawnictwo Naukowe UMK.

Solarczyk-Ambrozik E. (2013). Uczenie się przez całe życie jako rzeczywistość edukacyjna. W: Całożyciowe uczenie sie jako wyzwanie dla teorii i praktyki edukacyjnej. E. Solarczyk-Ambrozik (red.). Poznań: Wydawnictwo Naukowe UAM.

Solarczyk-Ambrozik E. (2018). Transformacja pracy i zatrudnienia a kariera zawodowa. Perspektywa jednostkowa i organizacyjna. W: Uczenie się przez całe życie. Rozwój-kariera-praca. Solarczyk-Ambrozik E., Barańska M. (red.). Poznań: Wydawnictwo Naukowe UAM. 
Solarczyk-Ambrozik E. (2020a), Doradztwo zawodowe-poradnictwo karierowe w obliczu nowych wyzwań. W: Społeczno-edukacyjny potencjał szkoły a rynek pracy. Christoph M., Wawrzyniak S. (red.). Poznań: Wydawnictwo Naukowe UAM.

Solarczyk-Ambrozik E. (2020b). Przeobrażenia pracy i zmian wzorów przebiegu karier a globalna kultura edukacyjna. W: Edukacja dorosłych a planowanie karier edukacyjno-zawodowych. Solarczyk-Ambrozik E., Christoph M., Konieczna-Woźniak R. (red.). Poznań: Wydawnictwo Naukowe UAM.

Strategia rozwoju kapitału ludzkiego 2020 (2013). Warszawa: Ministerstwo Pracy i Polityki Społecznej, s. 47.

Szmidt K.J. (2010). ABC Kreatywności. Warszawa: Wydawnictwo Difin.

Szmidt K.J. (2013). Pedagogika twórczości. Sopot: GWP.

Śliwerski B. (2009). Problemy współczesnej edukacji. Dekonstrukcja polityki oświatowej III RP. Warszawa: Wydawnictwa Akademickie i Profesjonalne.

Śliwerski B. (2013). Samowychowanie jako jeden z rodzajów uczenia się przez całe życie. W: Całożyciowe uczenie sie jako wyzwanie dla teorii i praktyki edukacyjnej. Solarczyk-Ambrozik E. (red.). Poznań: Wydawnictwo Naukowe UAM.

Tomaszewska R. (2020). „Ogrodnicy i rośliny”. Współczesna edukacja a rynek pracy przyszłości. W: Społeczno-edukacyjny potencjał szkoły a rynek pracy. Christoph M., Wawrzyniak S. (red.). Poznań: Wydawnictwo Naukowe UAM.

Wawrzonek A. (2018). Sukces i jego implikacje dla kształtowania tożsamości młodego człowieka. W: Uczenie się przez całe życie. Rozwój-kariera-praca. Solarczyk-Ambrozik E., Barańska M. (red.). Poznań: Wydawnictwo Naukowe UAM.

Włoch R., Śledziewska K. (2020). Gospodarka cyfrowa. Jak nowe technologie zmieniaja świat? Warszawa: Wydawnictwo Uniwersytetu Warszawskiego.

Wołk Z. (2013). Alternatywność dróg do pracy i zawodu w poprzemysłowym społeczeństwie wiedzy. W: Całożciowe uczenie się jako wyzwanie dla teorii i praktyki edukacyjnej. Solarczyk-Ambrozik E. (red.). Poznań: Wydawnictwo Naukowe UAM.

Netografia

Patrzylas A. (2016). Roboty „ida” po nasza pracę. Polska wśród najbardziej zagrożonych państw. Dostępny na: http://forsal.pl/artykuly/929689,automatyzacja-i-robotyzacja-pracy-wypieranie-ludzi-przez-maszyny-z-rynku-pracy.html (dostęp 17.03.2021).

https://www.ore.edu.pl/2017/10/o-projekcie/ (dostęp 14.03.2021).

https://sp8.krotoszyn.pl/strona-4227-informacje_o_projekcie.html (dostęp 15.03.2021)

Strategii na rzecz inteligentnego i zrównoważonego rozwoju sprzyjającego włączeniu społecznemu. Europa 2020 (Bruksela, 3.03.2010). Dostępny na: https://ec.europa. eu/eu2020/pdf/1_PL_ACT_part1_v1.pdf (dostęp 16.03.2021). 


\title{
A CHANGING SCHOOL FOR THE DEMANDS OF THE LABOR MARKET, AND MORE
}

\begin{abstract}
The aim of the article is to show the school in the context of the changing reality and requirements of the labor market. This article presents the modern dimensions of the school and examples of Model Training School projects. The issues of the development of the digital economy and the related competences of the future as well as the role of the teacher in a changing school are also discussed. The text is a compilation of reflections relating, on the one hand, to theoretical analyses and, on the other hand, to educational practice reflected in the author's professional experience.
\end{abstract}

Keywords: creativity, teacher, youth, graduate, labor market development strategy, education, school, contemporary. 